\title{
Impact of storage conditions on electromechanical, histological and histochemical properties of osteochondral allografts
}

Tomas Mickevicius ${ }^{1}$, Alius Pockevicius ${ }^{2}$, Audrius Kucinskas ${ }^{3}$, Rimtautas Gudas ${ }^{1,4}$, Justinas Maciulaitis 1,4, Aurelija Noreikaite $5^{5}$ and Arvydas Usas ${ }^{5^{*}}$

\begin{abstract}
Background: Osteochondral allograft transplantation has a good clinical outcome, however, there is still debate on optimization of allograft storage protocol. Storage temperature and nutrient medium composition are the most critical factors for sustained biological activity of grafts before implantation. In this study, we performed a time-dependent in vitro experiment to investigate the effect of various storage conditions on electromechanical, histological and histochemical properties of articular cartilage.

Methods: Osteochondral grafts derived from goat femoral condyles were frozen at $-70{ }^{\circ} \mathrm{C}$ or stored at $4{ }^{\circ} \mathrm{C}$ and $37^{\circ} \mathrm{C}$ in the medium supplemented with or without insulin-like growth factor-1 (IGF-1). After 14 and 28 days the cartilage samples were quantitatively analysed for electromechanical properties, glycosaminoglycan distribution, histological structure, chondrocyte viability and apoptosis. The results were compared between the experimental groups and correlations among different evaluation methods were determined.

Results: Storage at $-70{ }^{\circ} \mathrm{C}$ and $37^{\circ} \mathrm{C}$ significantly deteriorated cartilage electromechanical, histological and histochemical properties. Storage at $4{ }^{\circ} \mathrm{C}$ maintained the electromechanical quantitative parameter (QP) and glycosaminoglycan expression near the normal levels for 14 days. Although hypothermic storage revealed reduced chondrocyte viability and increased apoptosis, these parameters were superior compared with the storage at $-70{ }^{\circ} \mathrm{C}$ and $37{ }^{\circ} \mathrm{C}$. IGF-1 supplementation improved the electromechanical QP, chondrocyte viability and histological properties at $37^{\circ} \mathrm{C}$, but the effect lasted only 14 days. Electromechanical properties correlated with the histological grading score $(r=0.673, p<0.001)$, chondrocyte viability $(r=-0.654, p<0.001)$ and apoptosis $(r=0.416, p<0.02)$. In addition, apoptosis correlated with glycosaminoglycan distribution $(r=-0.644, p<0.001)$ and the histological grading score $(r=0.493, p=0.006)$.

Conclusions: Our results indicate that quality of allografts is better preserved at currently established $4{ }^{\circ} \mathrm{C}$ storage temperature. Storage at $-70^{\circ} \mathrm{C}$ or at $37^{\circ} \mathrm{C}$ is unable to maintain cartilage function and metabolic activity. IGF-1 supplementation at $37^{\circ} \mathrm{C}$ can enhance chondrocyte viability and improve electromechanical and histological properties of the cartilage, but the impact persists only 14 days. The correlations between cartilage electromechanical quantitative parameter (QP) and metabolic activity were detected. Our findings indicate that non-destructive assessment of cartilage by Arthro-BST is a simple and reliable method to evaluate allograft quality, and could be routinely used before implantation.
\end{abstract}

\footnotetext{
* Correspondence: arvydas.usas@lsmuni.lt

${ }^{5}$ Institute of Physiology and Pharmacology, Lithuanian University of Health

Sciences, Kaunas, Lithuania

Full list of author information is available at the end of the article
}

\section{Biomed Central}

(c) 2015 Mickevicius et al. Open Access This article is distributed under the terms of the Creative Commons Attribution 4.0 International License (http://creativecommons.org/licenses/by/4.0/), which permits unrestricted use, distribution, and reproduction in any medium, provided you give appropriate credit to the original author(s) and the source, provide a link to the Creative Commons license, and indicate if changes were made. The Creative Commons Public Domain Dedication waiver (http://creativecommons.org/publicdomain/zero/1.0/) applies to the data made available in this article, unless otherwise stated. 


\section{Background}

Articular cartilage injury is a frequent incidental finding during knee arthroscopic surgery [1, 2]. Large osteochondral defects in the knee joint present a very big challenge to the orthopaedic surgeons and remain an important risk factor for osteoarthritis development. Among numerous treatment options currently available in clinical practice, osteochondral transplantation is the only biological technique that can anatomically and functionally restore the hyaline cartilage [3-9]. Autologous osteochondral transplantation has demonstrated good to excellent clinical results [10-13], however, its use is limited due to the lack of healthy cartilage tissue and related donor site morbidity $[14,15]$.

Cartilage is avascular, aneural and relatively immunoprivileged tissue populated with chondrocytes residing within the extracellular matrix, thus, making it attractive for allogeneic transplantation [16, 17]. Efficacy of osteochondral allograft transplantation (OCA) has already been previously established [18-25]. However, its application is limited by the need for infectious disease screening, which requires extended allograft storage [26, 27]. Longterm in vitro maintenance of osteochondral allograft tissue poses a very big challenge, especially for cell viability. Chondrocyte viability is a major determinant of graft performance in vivo. Implantation of viable chondrocytes can assure prolonged maintenance of the extracellular matrix and integrity of the articular cartilage after transplantation. Despite numerous studies on allograft preparation, storage conditions and already approved protocols used by tissue banks, research on how to maintain viable cells is still ongoing $[18,28]$. Several studies have shown that deep freezing and cryopreservation leads to plummeted chondrocyte viability [29-31]. Hypothermic storage at $4{ }^{\circ} \mathrm{C}$, currently used by most tissue banks, has been shown capable of maintaining chondrocyte viability and matrix integrity [32-34]. Recently allograft storage at $37^{\circ} \mathrm{C}$ has been proposed, because superior results in comparison with refrigeration have been reported [29, 35].

Different storage media compositions have been used to improve chondrocyte survival during allograft storage. Serum-free medium $[19,35,36]$, fetal bovine serum (FBS) supplemented medium [29, 37], dexamethasone [38], etanercept [39] and platelet-rich plasma [40-42] have been used with varying success. Insulin-like growth factor-1 (IGF-1) is also considered to be a viable treatment option for osteochondral injuries. IGF-1 stimulates chondrocyte proliferation and synthesis of the extracellular matrix, and is chondroreparative $[42,43]$. These studies suggest a potential role of different biological regulators in cartilage repair, however, their appropriate dosing and impact on chondrocyte metabolic activity is unknown.

Research has shown that apoptosis or programmed cell death is crucial for maintaining the appropriate number of cells and tissue organization. Chondrocyte death by apoptosis has been linked with cartilage matrix degradation and initiation of osteoarthritic lesions [44, 45]. A substantial relationship between inhibition of chondrocyte apoptosis and improved chondrocyte viability during cold storage of osteochondral grafts has been demonstrated [46]. This study suggested that the apoptotic process could be manipulated to enhance chondrocyte survival and improve the results of osteochondral allograft transplantation. Robertson et al. have studied apoptotic gene expression in stored osteochondral allografts and found many apoptotic genes with prolonged storage [47].

Recently, a new technology has been employed to assess functional properties of the cartilage. Arthro-BST, an arthroscopic device, enables measurement of cartilage streaming potentials, which have been emphasized as an important parameter of cell and matrix viability [48]. Streaming potentials reflect cartilage composition and function, and are sensitive to degradative changes. It has been shown that the electromechanical measurements obtained with arthro-BST correlate with histological scores and biomechanical parameters, and provide rapid and reliable assessment of articular cartilage damage [49].

Progress in tissue transplantation, increased availability of fresh donor tissue, and greater demand, especially in athletic and aging population, may explain the growing need for allograft tarnsplantation procedures, which speed up recovery and help return to sports, or postpone arthroplasty for the elderly. However, the lack of clinical evidence on best preservation conditions for OCA requires more investigation on retaining chondrocyte viability and cartilage matrix integrity during allograft screening. Different storage conditions have to be reevaluated and an optimal allograft tissue storage protocol must then be proposed.

The purpose of this study was to assess electromechanical, histological and histochemical properties of articular cartilage after allograft storage for 14 and 28 days at $-70{ }^{\circ} \mathrm{C}, 4^{\circ} \mathrm{C}$ and $37^{\circ} \mathrm{C}$, and investigate the effect of IGF1 supplementation at $4{ }^{\circ} \mathrm{C}$ and $37{ }^{\circ} \mathrm{C}$. Secondarily, we aimed to examine the relationship between cartilage streaming potentials, measured by Arthro-BST device, and chondrocyte viability, apoptosis and histological evaluation.

\section{Methods}

\section{Osteochondral graft preparation and storage}

All experiments were approved by the Animal Health and Welfare Department, State Food and Veterinary Service. Osteochondral plugs, consisting of articular cartilage and subchondral bone ( $5 \mathrm{~mm}$ diameter), were harvested from medial femoral condyles of six 5 to 6-month old male Saanen goats using standard OATS technique (Arthrex Inc, USA) under sterile conditions. The samples were rinsed with phosphate-buffered saline (PBS; 
Sigma) supplemented with $100 \mathrm{U} / \mathrm{mL}$ penicillin, $100 \mu \mathrm{g} / \mathrm{mL}$ streptomycin and $0.25 \mu \mathrm{g} / \mathrm{mL}$ fungizone (PSF) (Sigma), and randomly allocated to the following groups $(n=6$ in each group): freshly harvested control (Fresh), frozen at $-70{ }^{\circ} \mathrm{C}\left(-70{ }^{\circ} \mathrm{C}\right)$, refrigerated at $4{ }^{\circ} \mathrm{C}$ in $100 \%$ atmospheric air $\left(4{ }^{\circ} \mathrm{C}\right)$, and incubated at $37{ }^{\circ} \mathrm{C}(95 \%$ humidity, $\left.5 \% \mathrm{CO}_{2}\right)\left(37{ }^{\circ} \mathrm{C}\right)$. The samples from $4{ }^{\circ} \mathrm{C}$ and $37^{\circ} \mathrm{C}$ groups were placed in 24-well plates containing low glucose Dulbecco's Modified Eagle's Medium (DMEM) (Sigma), supplemented with $10 \%$ fetal bovine serum (FBS) (Sigma), $1 \%$ of PSF), $2 \mathrm{mM} \mathrm{L-glutamine} \mathrm{(Sigma),}$ $25 \mu \mathrm{g} / \mathrm{mL} \mathrm{L}$-ascorbic acid (Sigma), and $0.1 \mathrm{mM}$ MEM non-essential amino acids solution (Sigma) with or without $100 \mathrm{ng} / \mathrm{mL}$ of IGF-1(Sigma). The samples were stored for 14 or 28 days. At the end of storage period, the osteochondral plugs were first analyzed for electromechanical properties, and then cut in half and subjected to further processing for evaluation of chondrocyte viability, apoptosis, glycosaminoglycan expression and histological scoring. The freshly harvested control samples were analyzed on the same day after collection (Fig. 1).

\section{Electromechanical measurements}

The electromechanical properties of the samples stored at different temperatures and nutritive medium conditions were evaluated with Arthro-BST ${ }^{\mathrm{nx}}$ (Biomomentum Inc., Laval, QC, Canada). The Arthro-BST is a relatively new medical device for non-destructive evaluation of articular cartilage electromechanical properties. The handheld hemispherical indenter containing an array of 37 gold microelectrodes $\left(5\right.$ microelectrodes $/ \mathrm{mm}^{2}$ ) records streaming potentials in the articular cartilage generated during gentle compression. During compression positive mobile ions in the interstitial fluid are displaced relative to the fixed negatively charged proteoglycan molecules, which are entrapped in the collagen network creating normal streaming potentials. In degenerated cartilage the network of collagen and proteoglycans is degraded leading to very low streaming potentials. A quantitative parameter (QP, arbitrary units), calculated by the computer software, corresponds to the number of microelectrodes in contact with the cartilage when the sum of streaming potentials reaches $100 \mathrm{mV}$. High QP indicates high compliance and, therefore, weak electromechanical properties reflecting poor load-bearing capacity of the cartilage. On the contrary, low QP indicates strong electromechanical properties and high load-bearing capacity [49]. Prior to testing, the ostochondral grafts were immersed in PBS solution for $20 \mathrm{~min}$ and the QP of each graft was recorded 5 times in order to obtain median values.

\section{Detection of chondrocyte viability}

Chondrocyte viability was analyzed using LIVE/DEAD assay (Molecular Probes, Eugene, OR, USA) staining and confocal microscopy. The samples were washed in PBS and then labelled with $1 \mu \mathrm{M}$ calcein AM (to detect live cells) and $2 \mu \mathrm{M}$ ethidium homodimer-1 (to detect dead cells). Thereafter, the samples were incubated for $40 \mathrm{~min}$ at $37{ }^{\circ} \mathrm{C}$, washed 3 times in $\mathrm{PBS}$ for $10 \mathrm{~min}$ and processed for imaging. $200 \mu \mathrm{m}$ thick slices were imaged along the vertical profile with inverted confocal microscope LSM 700 Axio Observer Z.1 (Carl Zeiss, Germany). Image stacks, consisting of 8 slices each at $0.74 \mu \mathrm{m}$ interval were obtained at $20 \mathrm{x}$ magnification. Live and dead cells were counted in 2 random areas $(200 \times 400 \mu \mathrm{m})$ in each tissue section using Image J version 1.47q (National Institutes of Health, Bethesda, MD, USA). Chondrocyte viability was calculated as a percentage of live cells relative to the total cell number.

\section{Histological evaluation}

The samples were fixed in $10 \%$ neutral buffered formalin, decalcified in Shandon TBD-2 Decalcifier (TBD; Thermo Scientific, Kalamazoo, MI, USA) and embedded in paraffin. Cartilage sections ( $5 \mu \mathrm{m}$ thick) were stained with safranin $\mathrm{O}$-fast green using an established protocol [50] to detect the glycosaminoglycan (GAG) positive matrix that is typical for the hyaline cartilage and normally stains red. Light microscopy images were taken at $4 \times$ magnification with Olympus BX63 microscope (Olympus, Japan) equipped with Olympus DP72 CCD camera using CellSens Dimension imaging software (Olympus, Japan). The images were analysed using Image J software. Previously described image processing protocol was adapted to quantify the amount of GAG distribution in each section [51]. Briefly, red colour intensity (RCI) was calculated in the entire cross-sectional slice area by obtaining red, green, and blue (RGB) image planes in a scale of 256 values (black $=0$ ). The fraction of red (RF) was defined as the ratio of the $R$ component to the sum of the $R, G$, and $B$ components: $R F=R /(R+$ $\mathrm{G}+\mathrm{B}$ ) and expressed as a percentage. Sections were additionally evaluated by 3 blinded observers using histological-histochemical grading system proposed by Mankin et al. [52]. Fresh articular cartilage received the score of 0 , whereas higher score indicated more deteriorated cartilage.

\section{TUNEL assay for chondrocyte apoptosis}

Apoptosis was evaluated with TUNEL assay kit (ApopTag ${ }^{\circ}$ Peroxidase In Situ Apoptosis Detection Kit; Millipore, USA) using the protocol provided by the manufacturer. Briefly, deparaffinised tissue sections were incubated in $20 \mu \mathrm{g} / \mathrm{mL}$ Proteinase $\mathrm{K}$ (Ambion) for $15 \mathrm{~min}$ at room temperature. After endogenous peroxidase has been quenched by incubation in $3 \%$ hydrogen peroxide for 5 min, the ends of fragmented DNA in the tissue were labelled with terminal deoxynucleotidyl transferase (TdT) 


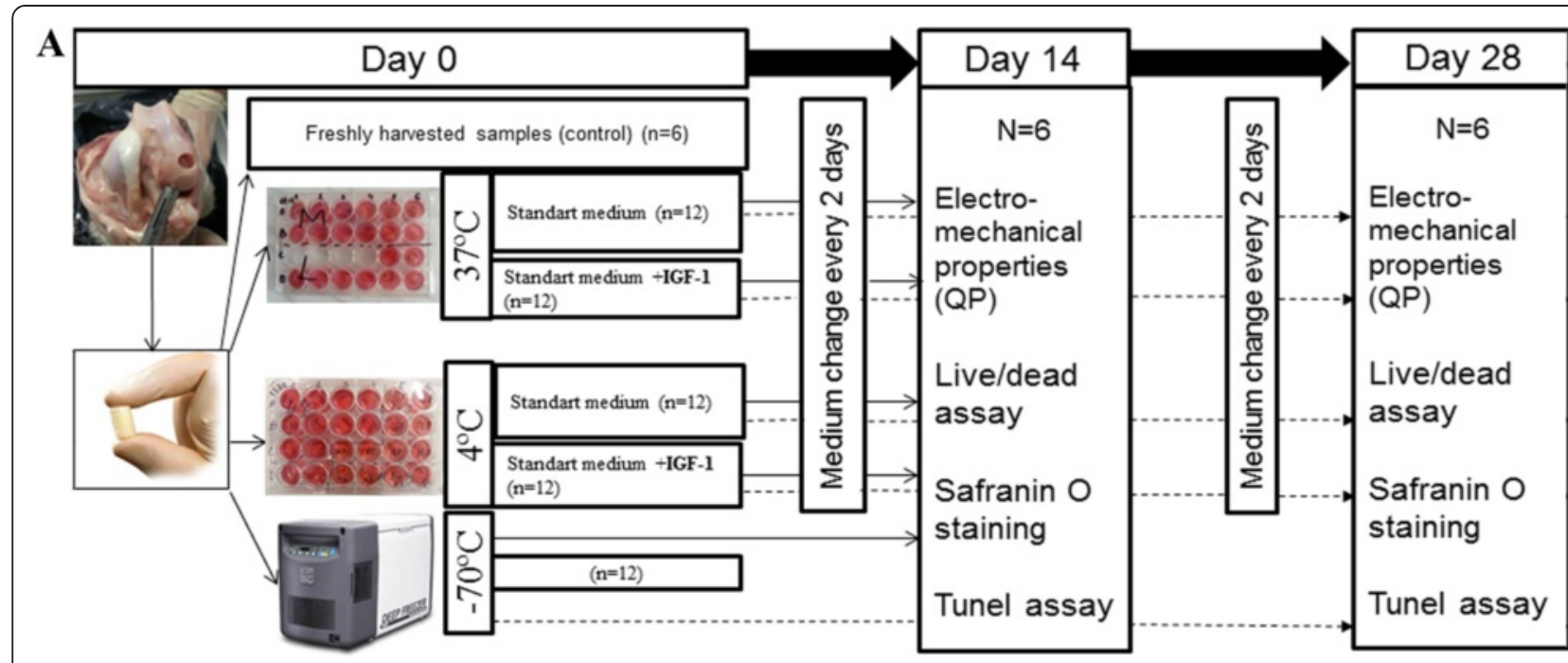

B

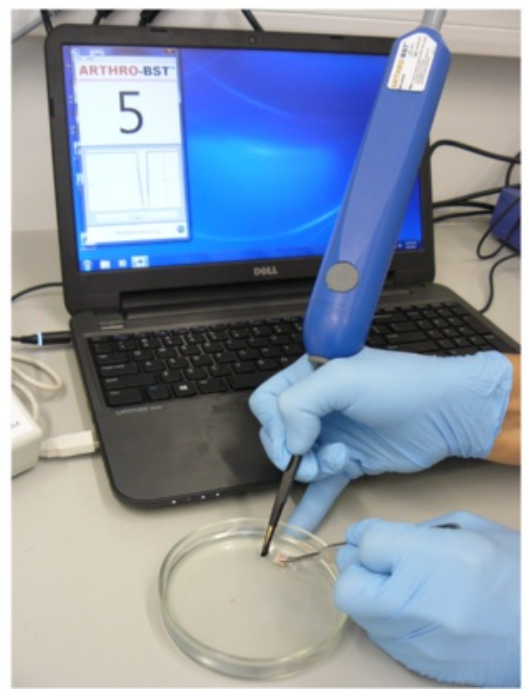

C

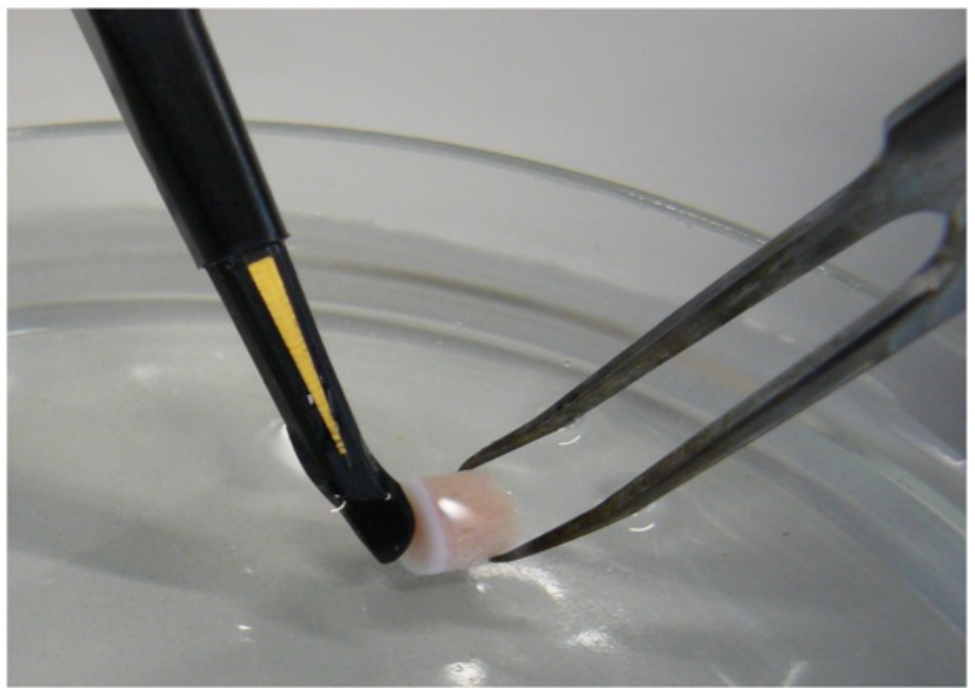

Fig. 1 Sketch of the experimental setup. a The design of experimental setting showing different allograft storage conditions and evaluation time points. b, $\mathbf{c}$ In vitro evaluation of the graft electromechanical properties with Arthro-BST

enzyme in the presence of digoxigenin-conjugated nucleotides and unlabeled nucleotides for $60 \mathrm{~min}$ in humidified chamber at $37{ }^{\circ} \mathrm{C}$. The slides were then incubated for $30 \mathrm{~min}$ with anti-digoxigenin antibodies conjugated to a peroxidase reporter molecule. Immunohistochemical detection of these antibodies was carried out by exposure to a chromogenic DAB substrate (Sigma) for $10 \mathrm{~min}$. The slides were counterstained with Methyl Green (Sigma) solution for $5 \mathrm{~min}$, rinsed in distilled water, dehydrated in alcohol, cleared in xylenes, and mounted with cytoseal under a coverglass.

High magnification images $(200 \times)$ were obtained with Olympus BX63 microscope (Olympus, Japan). The number of apoptotic (brown-black) and viable (green) cells was counted in 3 random areas $(200 \times 400 \mu \mathrm{m})$ selected in two tissue sections from each sample. The percentage of apoptotic cells was then calculated.

\section{Statistical analyses}

The data were analyzed using the SPSS v.19. All results are presented as the mean \pm standard deviation. Statistical differences between the sample groups were assessed using one-way repeated measures analysis of variance (ANOVA) with Bonferroni post hoc multiple comparison test. $p<0.05$ was considered statistically significant. The relationship between the QP, chondrocyte viability, apoptosis, GAG distribution and histological grading scores was assessed by nonparametric correlation analysis using 
Spearman's correlation coefficient. A significant correlation was present when $p<0.05$.

\section{Results}

Electromechanical properties of osteochondral grafts

The QP of the freshly harvested samples on average was $4 \pm 0.23$ (Fig. 2). We observed significantly increased QP after 14 days for the samples stored at $-70{ }^{\circ} \mathrm{C}$ or incubated in DMEM at $37{ }^{\circ} \mathrm{C}(5.6 \pm 0.49$ and $5.57 \pm 0.43$, respectively; $p<0.001$ ). For the samples stored in DMEM at $4{ }^{\circ} \mathrm{C}$, we detected a slightly increased QP $(4.43 \pm 0.15)$, however, QP was significantly lower compared to both aforementioned groups $(p<0.001)$. When the culture medium was supplemented with IGF-1, there was a slight increase of QP for the grafts stored at $4{ }^{\circ} \mathrm{C}(4.53 \pm 0.27)$, however, a considerable decrease of QP was detected for the grafts stored at $37^{\circ} \mathrm{C}(4.77 \pm 0.32 ; p=0.043)$.

After 28 days of storage, electromechanical properties of the samples worsened. For the samples stored at $-70{ }^{\circ} \mathrm{C}$, only a slight increase of QP $(5.93 \pm 0.33)$ was detected. For the grafts incubated in DMEM at $37{ }^{\circ} \mathrm{C}$, we observed a significant increase of QP $(6.63 \pm 0.34 ; p=0.001)$ when compared to 14-day storage period. Although there was a diminutive increase of $\mathrm{QP}$ in the refrigeration group $(5.17 \pm 0.34)$, it was significantly lower compared to the incubation at $37{ }^{\circ} \mathrm{C}$ group $(p<0.001)$. The addition of IGF-1 to the culture medium at this time had no significant effect on QP at $4{ }^{\circ} \mathrm{C}$ and $37{ }^{\circ} \mathrm{C}$. These findings clearly indicate that allograft refrigeration has a greater capacity of preserving electromechanical properties of the osteochondral grafts compared to freezing or incubation at $37{ }^{\circ} \mathrm{C}$ and could prevent rapid deterioration of the cartilage.

\section{Chondrocyte viability}

Chondrocyte viability for the freshly harvested articular cartilage was approximately $83.3 \pm 2.98 \%$ (Fig. 3a, b). We detected a significant decrease of chondrocyte viability in all the storage groups after 14 and 28 days $(p<0.001)$ compared to fresh cartilage samples. The samples stored at $-70{ }^{\circ} \mathrm{C}$ contained smallest amount of viable chondrocytes compared with any other storage group. After 14 days, the $-70{ }^{\circ} \mathrm{C}$ samples contained only $35.2 \pm 6.9 \%$ of viable chondrocytes, whereas samples stored in DMEM medium at $37^{\circ} \mathrm{C}$ contained $44.87 \pm 4.53 \%$ of viable chondrocytes. No significant difference was detected between these two groups. For the samples stored in DMEM at $4{ }^{\circ} \mathrm{C}$, viability was $58.22 \pm 4.07 \%$ and it was significantly higher compared with the $-70{ }^{\circ} \mathrm{C}$ and $37{ }^{\circ} \mathrm{C}$ storage groups $(p<0.001$ and $p<0.003$, respectively). When IGF-1 was added to the medium, chondrocyte viability decreased in the $4{ }^{\circ} \mathrm{C}$ storage group $(53.89 \pm$ $6.48 \%$ ) and increased in the $37{ }^{\circ} \mathrm{C}$ storage group $(49.22 \pm 7.35 \%)$, but this change was not significant.

After 28 days, the samples stored at $-70{ }^{\circ} \mathrm{C}$ contained significantly less viable chondrocytes $(35.46 \pm 4.36 \%)$ compared with any other storage group $(p \leq 0.001)$. There was no significant difference in chondrocyte viability between the samples stored at $37{ }^{\circ} \mathrm{C}$ and $4{ }^{\circ} \mathrm{C}$ $(52.02 \pm 5.97 \%$ and $57.80 \pm 2.71 \%$, respectively). When IGF-1-supplemented medium was used, chondrocyte viability slightly decreased in the $4{ }^{\circ} \mathrm{C}$ and $37{ }^{\circ} \mathrm{C}$ groups $(53.81 \pm 4.90 \%$ and $49.93 \pm 4.96 \%$, respectively). These results suggest that storage at $-70{ }^{\circ} \mathrm{C}$ is unable to maintain chondrocyte viability. Storage at $4{ }^{\circ} \mathrm{C}$ is capable of maintaining significantly higher chondrocyte viability than storage at $37{ }^{\circ} \mathrm{C}$, but this effect lasts only 2 weeks.

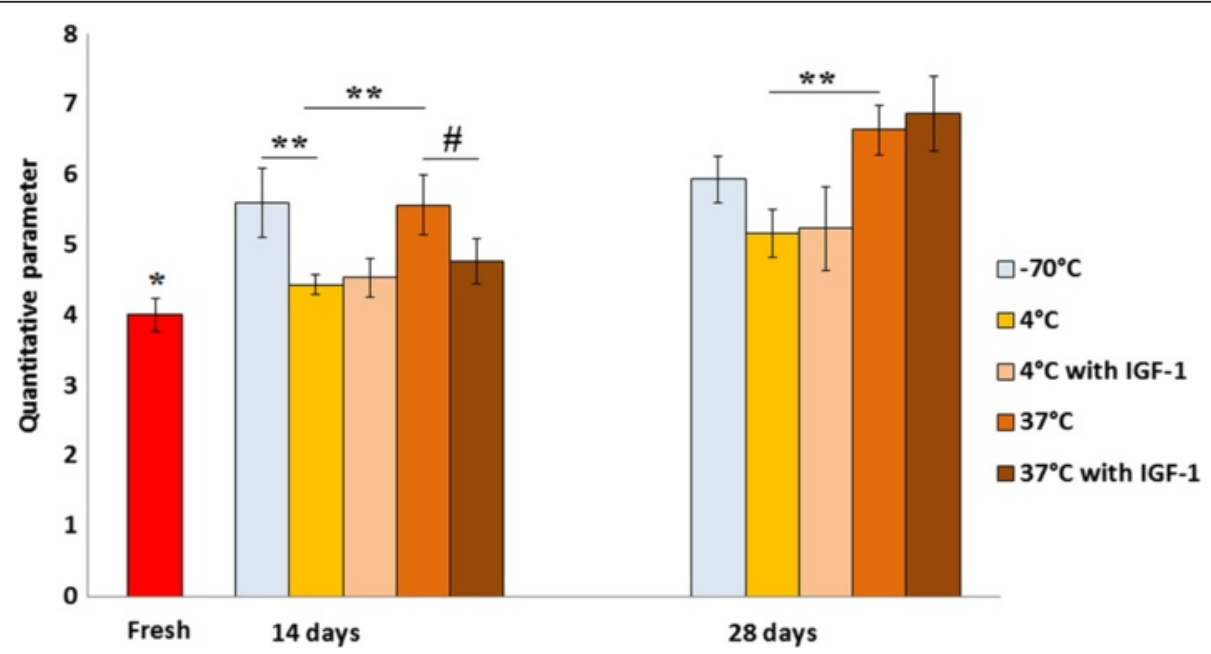

Fig. 2 Electromechanical properties of osteochondral samples, as analyzed by Arthro-BST. Electromechanical properties of samples stored in different temperature and nutritive medium conditions were evaluated after 14 and 28 days. Freshly harvested cartilage was used as control. Quantitative parameter (QP) measurements are presented as arbitrary units (mean \pm standard deviation). ${ }^{*} p<0.001$ (fresh versus $-70{ }^{\circ} \mathrm{C}$ and $37^{\circ} \mathrm{C}$ group after 14 days, and versus all other groups after 28 days); ${ }^{* *} p<0.001 ; * p<0.05$ 


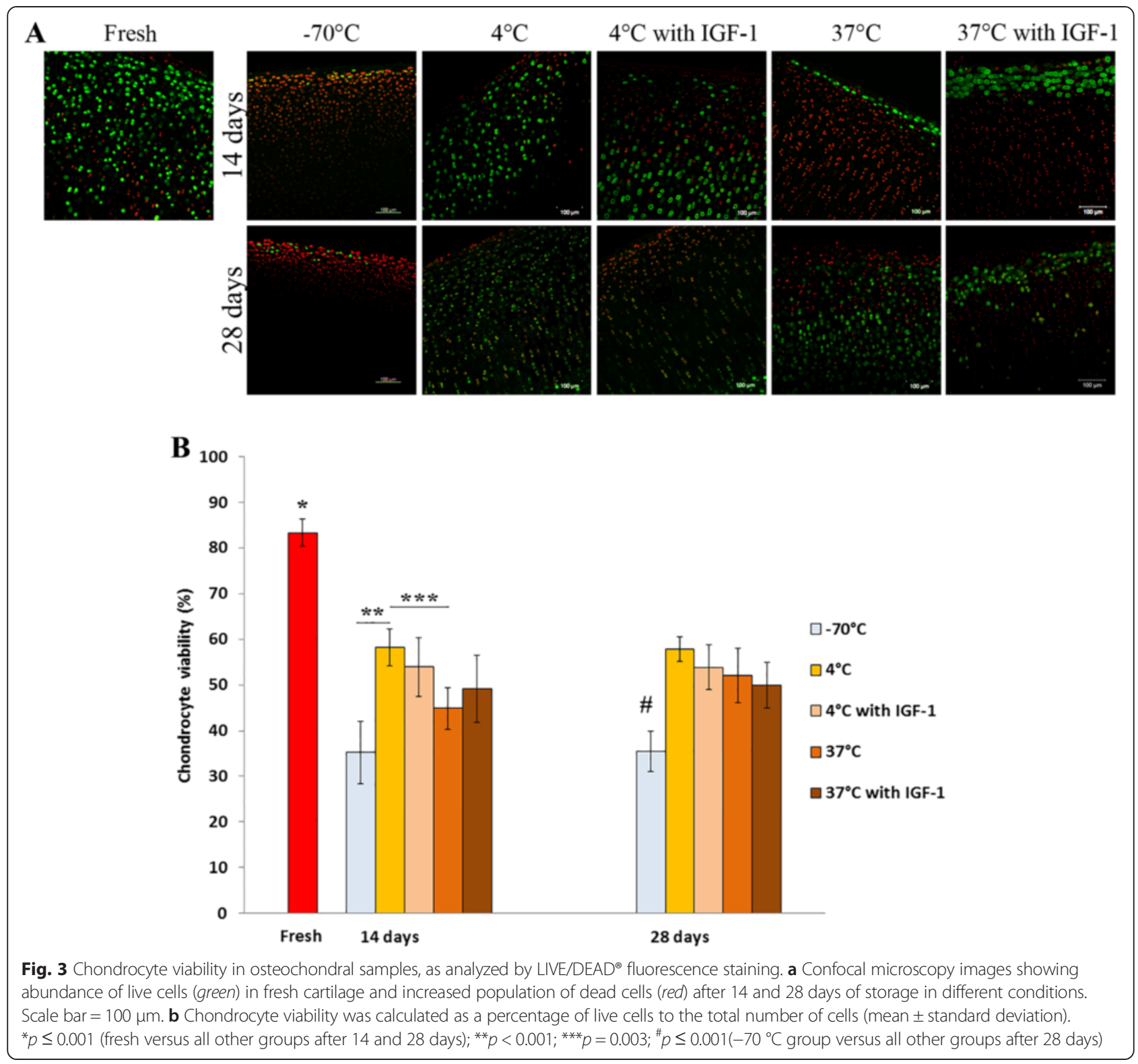

IGF-1 supplementation increased chondrocyte viability at $37{ }^{\circ} \mathrm{C}$ during 14-day storage, but did not reveal a profound effect at any time at $4{ }^{\circ} \mathrm{C}$ and $37{ }^{\circ} \mathrm{C}$ after 28 days.

\section{GAG quantification by safranin $\mathrm{O}$ staining}

Cartilage sections from all sample groups were stained with safranin O-fast green and evaluated for GAG distribution (Fig. 4a). Red colour intensity (RCI) of the freshly extracted normal articular cartilage was $72.95 \pm 1.06 \%$ (Fig. 4b). We observed a significant reduction of RCI after storage at $-70{ }^{\circ} \mathrm{C}$ for 14 days $(61.50 \pm 9.60 \% ; p=0.018)$. RCI of samples stored in DMEM at $4{ }^{\circ} \mathrm{C}$ remained very close to a fresh cartilage level $71.48 \pm 5.61 \%$. When IGF1 was added to the medium at $4{ }^{\circ} \mathrm{C} \mathrm{RCI}$ decreased to $62.58 \pm 9.57 \%$, but this change was not significant.
For the samples stored in DMEM at $37^{\circ} \mathrm{C}$, we observed a significant reduction of RCI compared with the fresh and refrigerated samples $(54.4 \pm 1.76 \% ; p \leq 0.001)$. When IGF1 was added to the medium at $37{ }^{\circ} \mathrm{C}, \mathrm{RCI}$ increased to $63.98 \pm 9.35 \%$, but this increase was not significant. After 28 days, RCI for all the samples was significantly lower compared with the fresh samples and constituted $57.89 \pm$ $2.31 \%, 59.02 \pm 5.46 \%$ and $48.58 \pm 3.43 \%$, for $-70{ }^{\circ} \mathrm{C}, 4{ }^{\circ} \mathrm{C}$ and $37{ }^{\circ} \mathrm{C}$ storage groups, respectively $(p<0.002)$. A significant reduction of RCI compared with a 14-day storage period was detected in the samples stored in DMEM at $4{ }^{\circ} \mathrm{C}(p=0.078)$. When IGF- 1 was added to the storage medium at $4{ }^{\circ} \mathrm{C}$ and $37{ }^{\circ} \mathrm{C}$, RCI decreased to $54.12 \pm$ $7.27 \%$ and $45.91 \pm 4.1 \%$, respectively. There was no statistically significant difference between the groups after 


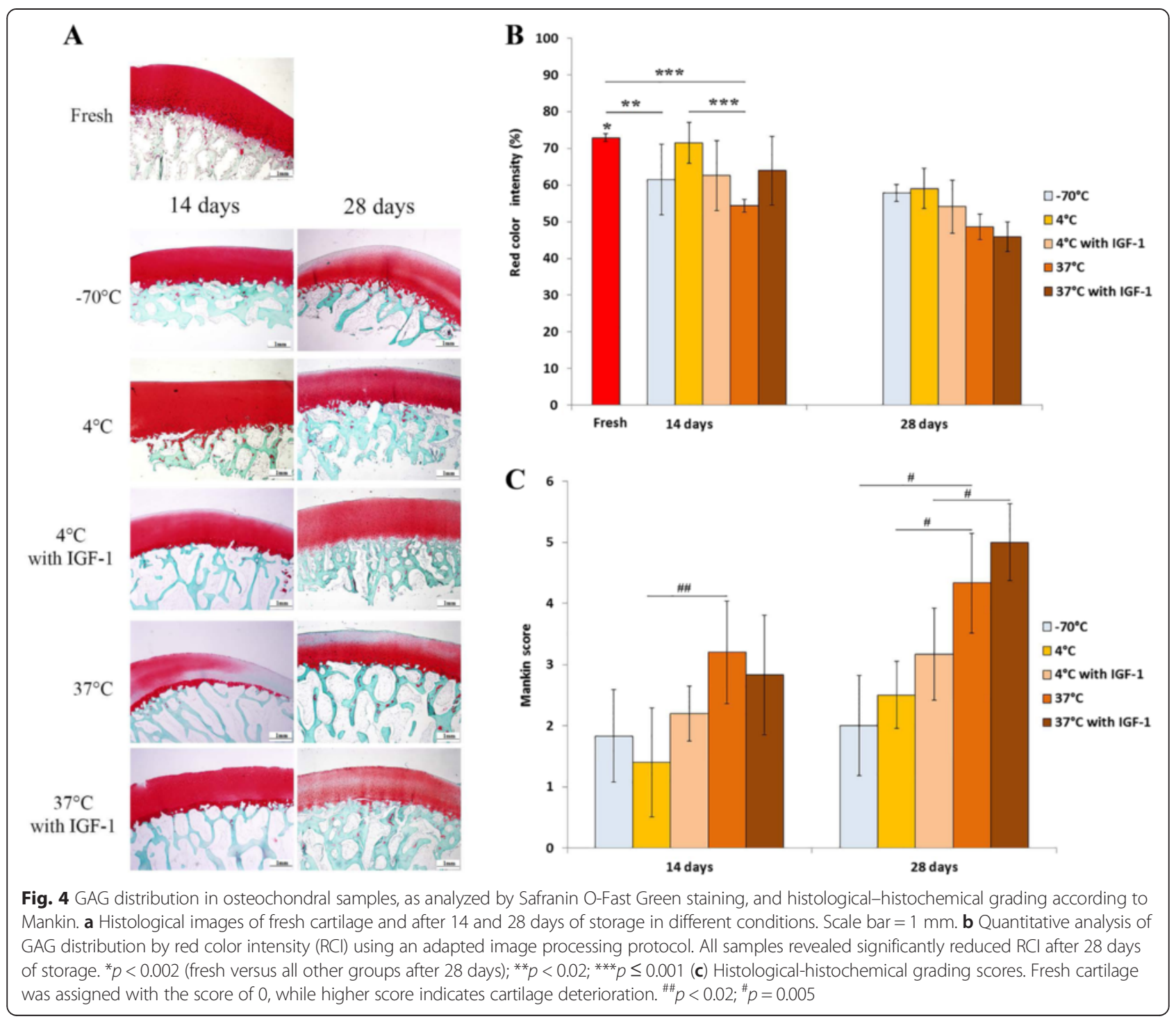

28 days. These results indicate that allograft storage at $4{ }^{\circ} \mathrm{C}$ maintains $\mathrm{GAG}$ distribution near the normal levels for 14 days and is superior compared with storage at $37{ }^{\circ} \mathrm{C}$. IGF-1 supplementation did not help to maintain GAG distribution at $4{ }^{\circ} \mathrm{C}$, but facilitated these properties at $37{ }^{\circ} \mathrm{C}$. However, during extended storage GAG distribution decreased and there was no significant difference between the groups.

\section{Histological grading}

We also analyzed whether different storage conditions had effect on histopathology. We used the histologicalhistochemical grading system proposed by Mankin et al. [52]. Even though this method is intended to be used for the grading of the human osteoarthritic cartilage, it has also been used in animal studies [53, 54]. After 14 days, the samples stored at $-70{ }^{\circ} \mathrm{C}$ and $4{ }^{\circ} \mathrm{C}$ exhibited slightly reduced safranin $\mathrm{O}$ staining with diffuse hypercellularity at the superficial cartilage layer and received the scores of $1.83 \pm 0.75$ and $1.4 \pm 0.89$, respectively (Fig. 4c). In contrast, the samples stored at $37{ }^{\circ} \mathrm{C}$ received a score of $3.2 \pm 0.84$ because of structural irregularities, hypocellularity and clonal cells, which were accompanied by a slight reduction in safranin $\mathrm{O}$ staining throughout the superficial and middle layer of the cartilage. In addition, the histological score in the $37^{\circ} \mathrm{C}$ group was significantly higher $(p=0.019)$ compared with the $4{ }^{\circ} \mathrm{C}$ group, indicating more rapid cartilage deterioration. The histological scores after 28 days increased in each group. The samples stored at $37{ }^{\circ} \mathrm{C}$ received significantly higher scores compared with the $-70{ }^{\circ} \mathrm{C}$ and $4{ }^{\circ} \mathrm{C}$ groups $(4.33 \pm 0.82$ versus $2.0 \pm 0.82$ and $2.5 \pm 0.55$, respectively; $p=0.005$ ), as was evident by a more diffuse hypercellularity and markedly reduced safranin $\mathrm{O}$ staining throughout the samples.

IGF-1 addition to the medium at $4{ }^{\circ} \mathrm{C}$ and $37{ }^{\circ} \mathrm{C}$ had no profound effect on the histological scores compared 
with DMEM alone after 14 days of storage, although a slight improvement was detected at $37^{\circ} \mathrm{C}$. Higher histological scores were observed after 28 days, but significant increase compared with the 14-day period was detected only in the $37{ }^{\circ} \mathrm{C}$ group $(p<0.001)$ after IGF-1 supplementation. Increased diffuse hypercellularity was evident in both IGF-1 supplemented groups after prolonged storage. In addition, inferior surface structure, moderate to severe reduction in safranin $\mathrm{O}$ staining and clonal cellularity with hypocellular areas were notable throughout the $37{ }^{\circ} \mathrm{C}$ samples after 28 days of storage.

\section{Chondrocyte apoptosis}

The extent of chondrocyte apoptosis varied among different storage groups. The freshly harvested samples contained on average $54.55 \pm 8.87 \%$ of TUNEL positive chondrocytes (Fig. 5). After 14 days, a significant increase in apoptotic chondrocyte number was observed at $-70{ }^{\circ} \mathrm{C}$ and $37{ }^{\circ} \mathrm{C}(85.82 \pm 8.72 \%$ and $93.91 \pm 1.1 \%$, respectively; $p<0.001)$. Albeit it was a significant increase in the $4{ }^{\circ} \mathrm{C}$ group $(74.98 \pm 8.67 \% ; p=0.021)$, this group contained considerably less $(p=0.015)$ apoptotic chondrocytes compared with the $37{ }^{\circ} \mathrm{C}$ storage group. IGF-1 supplementation had no profound effect on apoptosis at $4{ }^{\circ} \mathrm{C}$ and $37^{\circ} \mathrm{C}$.

After 28 days, the percentage of apoptotic chondrocytes in each group did not change significantly when compared with the 14-day storage. Yet again, we detected significantly less apoptotic chondrocytes in the refrigeration group compared with the $37{ }^{\circ} \mathrm{C}$ storage group (74.39 \pm $3.60 \%$ and $94.32 \pm 1.90 \%$, respectively; $p=0.008)$. IGF-1 addition at this time also did not altered apoptosis at $4{ }^{\circ} \mathrm{C}$ and $37^{\circ} \mathrm{C}$. These findings indicate that allograft storage at $4{ }^{\circ} \mathrm{C}$ is associated with a lesser extent of apoptosis than storage at $37{ }^{\circ} \mathrm{C}$. IGF-1 had no impact on chondrocyte apoptosis in any group at any time.

\section{Correlations between different quantitative parameters}

The statistical analysis revealed that the electromechanical QP correlated directly with the histological grading score
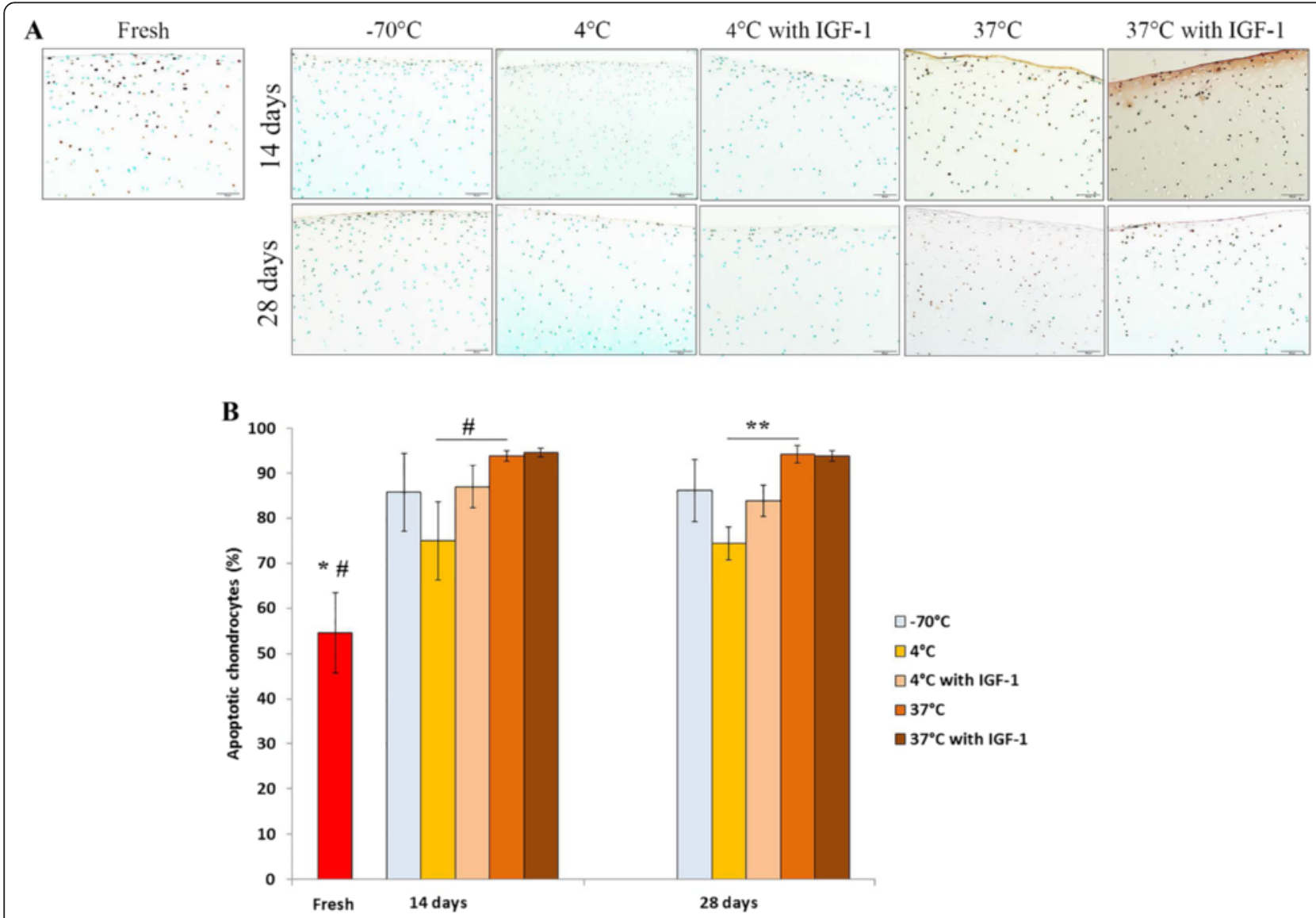

Fig. 5 Chondrocyte apoptosis in osteochondral samples, as analyzed by TUNEL immunoassay to detec apoptotic cells. a Light microscopy images showing abundance of viable cells (green) in fresh cartilage and increased population of apoptotic cells (brown-black) after 14 and 28 days of storage in different conditions. Scale bar $=50 \mu \mathrm{m}$. $\mathbf{b}$ The percentage of apoptotic cells was calculated as the number of apoptotic cells related to the total number of cells. Apoptosis significantly increased throughout different storage groups. ${ }^{*} p<0.001$ (fresh versus all other groups, except $4{ }^{\circ} \mathrm{C}$ after 14 and 28 days); $\# p<0.05$ (fresh versus $4{ }^{\circ} \mathrm{C}$ after 14 and 28 days); ${ }^{*} p=0.008$ 
$(r=0.673, p<0.001)$, apoptotic chondrocytes $(r=0.416$, $p=0.018)$, and inversely with chondrocyte viability $(r=-0.654, p<0.001)$ (Fig. 6). In addition, the extent of apoptosis correlated directly with the histological grading score $(r=0.493, p=0.006)$ and inversely with GAG distribution manifested by RCI measurement $(r=-0.644, p<0.001)$

\section{Discussion}

Our results demonstrate that the cartilage samples stored at $4{ }^{\circ} \mathrm{C}$ possessed higher chondrocyte viability and GAG distribution, lower apoptosis and nearly normal electromechanical properties compared with the samples stored at $37{ }^{\circ} \mathrm{C}$. These improvements were apparent throughout 28 days. However, there was no significant difference in chondrocyte viability and GAG expression between two groups after 28 days. Our results did not support previous studies which indicate that allograft storage at $37{ }^{\circ} \mathrm{C}$ is superior to storage at $4{ }^{\circ} \mathrm{C}$. Garrity et al. found that osteochondral allograft viability, matrix content, composition and biomechanical properties were maintained at 'fresh' levels through 56 days of storage in the standard medium at $37{ }^{\circ} \mathrm{C}$, but allografts stored at $4{ }^{\circ} \mathrm{C}$ were unable to maintain viability or matrix integrity through 28 days of storage [35]. In distinction to the latter study, which used a serum-free medium, we used $10 \%$ FBS-supplemented medium. Numerous studies have demonstrated that addition of FBS to the nutrient media can significantly increase chondrocyte survival during storage at $4{ }^{\circ} \mathrm{C}[32,37,43]$. Pallante et al. reported that chondrocyte viability was higher after storage at $37{ }^{\circ} \mathrm{C}$, instead of $4{ }^{\circ} \mathrm{C}$, while cartilage thickness, GAG and collagen content were maintained at both temperatures [29]. In that study $4{ }^{\circ} \mathrm{C}$ samples were stored in $10 \%$ FBS-supplemented medium preequilibrated to $5 \% \mathrm{CO}_{2}$ and tightly sealed. By contrast, in this study the specimens were stored in 24-well plates exposed to $100 \%$ atmospheric air with medium change three times per week. Prior studies have also suggested that replenishment of nutrients by regular changes of the medium may enhance chondrocyte survival in hypothermically stored cartilage specimens $[32,55]$.

We also detected that storage at $-70{ }^{\circ} \mathrm{C}$ was associated with significant decline in chondrocyte viability and
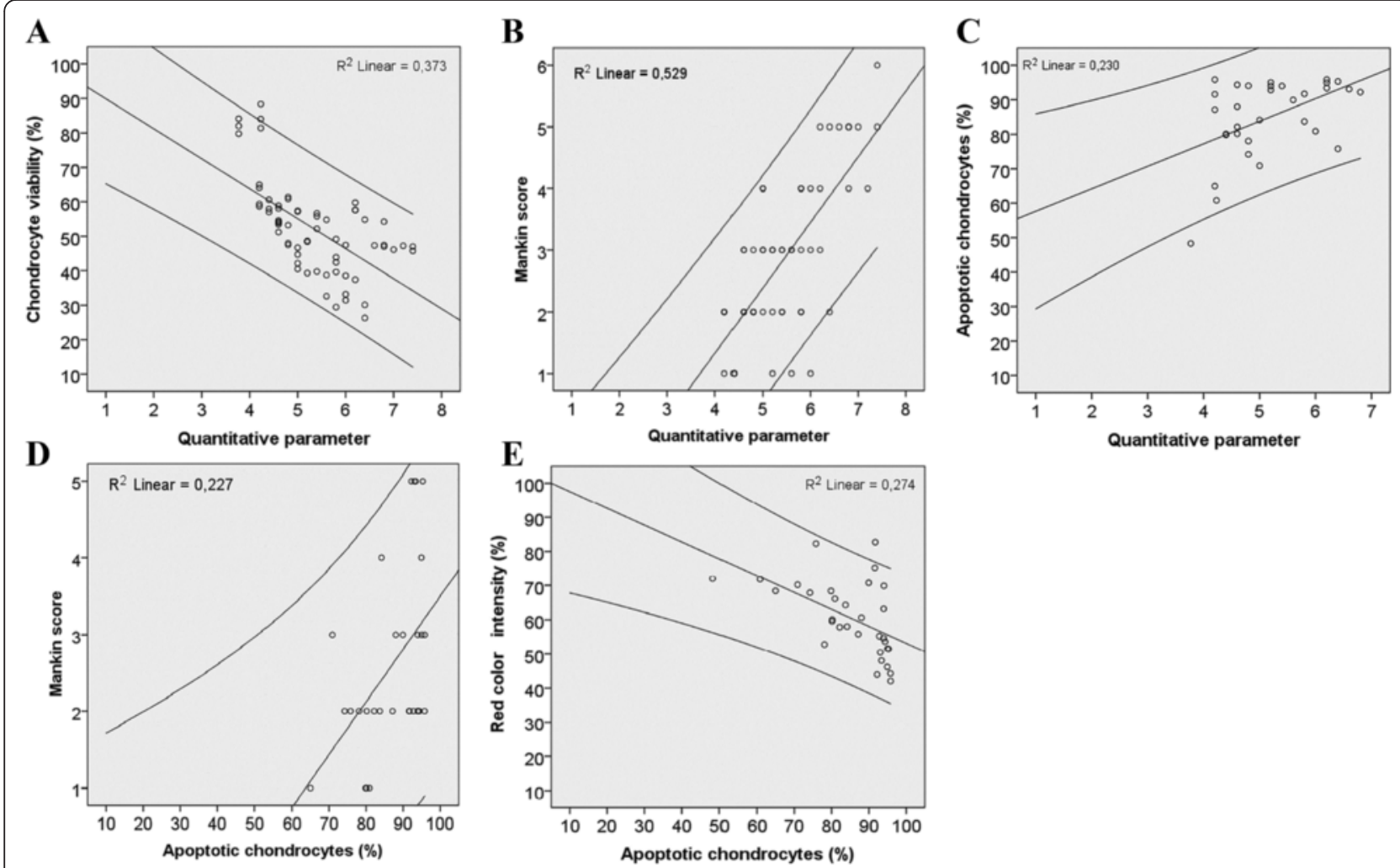

Fig. 6 Correlations between different quantitative parameters. Bivariate linear correlations were assessed using Spearman's correlation coefficient. a Inverse correlation between chondrocyte viability (\%) and quantitative parameter (QP). Correlation coefficient $(r=-0.654)$, corresponding P-value ( $p<0.01)$; (b) Direct correlation between Mankin score and QP. Correlation coefficient $(r=0.673)$, corresponding P-value $(p<0.01)$; (c) Direct correlation between apoptotic chondrocytes (\%) and QP. Correlation coefficient $(r=0.416)$, corresponding P-value $(p<0.01)$; (d) Direct correlation between Mankin score and apoptotic chondrocytes (\%). Correlation coefficient $(r=0.493)$, corresponding P-value $(p<0.01)$; (e) Inverse correlation between red color intensity (\%) and apoptotic chondrocytes (\%). Correlation coefficient $(r=-0.644)$, corresponding P-value $(p<0.01)$ 
worse electromechanical properties compared to storage at $4{ }^{\circ} \mathrm{C}$. These results support previous findings that deep freezing leads to dramatic loss of viable chondrocytes [29]. In fact, our results conflict previous findings that storage at $-80{ }^{\circ} \mathrm{C}$ does not change the mechanical properties of articular cartilage [19, 55-57]. Even though we did not assess biomechanical properties of the grafts, recent studies demonstrated significant correlation between electromechanical and biomechanical parameters $[49,58]$.

There is a limited number of studies that have investigated the IGF-1 effect on chondrocyte viability during allograft storage. Teng et al. [43] used a serum-free medium at $4{ }^{\circ} \mathrm{C}$ and reported that viability after 3 weeks was significantly higher in DMEM + IGF-1 group compared with DMEM alone group. However, after 4 weeks researchers observed near a 10 -fold decrease in the DMEM + IGF-1 group compared with a 2-fold decrease in the DMEM alone group. Several reports have indicated that IGF-1 can decrease chondrocyte apoptosis induced by traumatic compression or collagenases treatment $[59,60]$. In this study the addition of IGF-1 to DMEM at $4{ }^{\circ} \mathrm{C}$ did not produce a favourable effect on chondrocyte viability, apoptosis and GAG distribution, but the electromechanical properties in both groups were quite similar and remained near normal levels after 14 and 28 days. Interestingly, it was found that IGF-1 supplementation at $37{ }^{\circ} \mathrm{C}$ had a positive effect on chondrocyte viability, GAG distribution and significantly improved the electromechanical QP. However, these improvements lasted only for 14 days and eventually, after 28 days, all the parameters became worse compared with the samples stored in DMEM without IGF-1.

Non-destructive evaluation of electromechanical properties by Arthro-BST is a relatively new technique in cartilage research and it has already been shown very useful for quantitative assessment of functional properties in cartilage repair studies $[48,49,58]$. It has been reported that electromechanical measurements reflect cartilage material properties and are even more sensitive to the changes than biomechanical testing [58]. Although we did not detect correlation between electromechanical QP and GAG distribution $(p=0.059)$, our findings are consistent with other studies demonstrating that the electromechanical QP correlated directly with the Mankin score [49, 61]. Cartilage cellular impairment and subsequent reduction of safranin-O staining was reflected by increased QP values. In addition, it was observed that the electromechanical properties correlated with the chondrocyte viability and apoptosis as reflected by relatioship between higher QP, reduced viability and increased apoptosis. To our knowledge, this is the first report when electromechanical properties of the articular cartilage were linked with these biological parameters.
It has been reported that chondrocyte death by apoptosis is closely associated with cartilage matrix degradation which is crucial for osteoarthritis development [44]. Decreased cell viability and increased apoptosis was also detected after a traumatic joint injury [62]. Although we did not observe correletion between viability and apoptosis $(p=0.051)$, we found that apoptosis correlated directly with Mankin score and inversely with proteoglycan distribution as assessed by safranin-O staining. These findings are consistent with previous reports indicating significant linear relationship between the histopathological grade of cartilage and chondrocyte apoptosis [44, 63, 64].

One limitation of this study could be relatively small number of samples per experimental group. However, only one subjective parameter of histological grading and four quantitative evaluation parameters used in our study confirm reliability of the obtained data. In fact, the correlation analyses performed at each designated timepoint revealed similar relationship between aforementioned parameters after 14 and 28 days. To further investigate correlations between different storage groups more samples would be required. Another limitation related to our study was previously descibed by Sim et al. [49]. Although this study found no correlation between electromechanical QP and human cartilage thickness, authors indicated that it could be difficult to distinquish high electromechanical properties of the cartilage for low QP $(<4)$ due to the geometry of Arthro-BST indenter and its limitations for thin cartilage. Regardless the fact that the goat knee articular cartilage is substantialy thinner compared to human [65], like in their study, this limitation caused no problem for us since the lowest average QP was 4.

\section{Conclusions}

Our results indicate that the quality of stored allografts is better preserved at currently established refrigeration temperatures compared with the storage at very low temperatures or incubation at $37{ }^{\circ} \mathrm{C}$. IGF-1 supplementation at $37{ }^{\circ} \mathrm{C}$ can enhance chondrocyte viability, improve electromechanical and histological properties of the cartilage, but the effect is diminished beyond 14 days. The nondestructive evaluation of cartilage by the Arthro-BST enables a rapid, convenient and reliable way to estimate allograft quality before implantation and warrants ordinary use of this device in assessing articular cartilage damage during arthroscopic surgery. In addition, this method could provide precise information regarding efficacy of surgical cartilage repair and is a promising technique for monitoring the outcome of regenerative processes.

Competing interests

The authors declare that they have no competing interests. 


\section{Authors' contributions}

TM participated in the design of the experiment, carried out the experimentation and analysis of the data. AP was involved in data acquisition, analysis and interpretation. AK participated in the design of the experiment and data aquisition. RG made substantial contribution to concept and design of the experiment, and has been involved in drafting the manuscript and revising it critically. JM was involved in analysis and interpretation of data, also participated in drafting the manuscript and revising it critically. AN participated in drafting the manuscript and revising it critically. AU participated in the design of the experiment, carried out experimentation, drafted the manuscript. All authors read and approved the final manuscript

\section{Acknowledgements}

This research was funded by the European Social Fund under the Global Grant measure (VP1-3.1-SMM-07-K-03-078). The authors wish to thank Dr. Sergej Sosunkevich and Hermanas Inokaitis (Lithuanian University of Health Sciences, Institute of Anatomy) for their help with confocal microscopy.

\section{Author details}

'Department of Orthopaedics and Traumatology, Hospital of Lithuanian University of Health Sciences Kaunas Clinics, Kaunas, Lithuania. ${ }^{2}$ Pathology Center, Department of Infectious Diseases, Veterinary Academy, Lithuanian University of Health Sciences, Kaunas, Lithuania. 'arge Animal Clinic, Veterinary Academy, Lithuanian University of Health Sciences, Kaunas, Lithuania. ${ }^{4}$ Institute of Sports, Lithuanian University of Health Sciences, Kaunas, Lithuania. ${ }^{5}$ Institute of Physiology and Pharmacology, Lithuanian University of Health Sciences, Kaunas, Lithuania.

\section{Received: 15 July 2015 Accepted: 15 October 2015 Published online: 23 October 2015}

\section{References}

1. Curl WW, Krome J, Gordon ES, Rushing J, Smith BP, Poehling GG. Cartilage injuries: a review of 31,516 knee arthroscopies. Arthrosc J Arthrosc Relat Surg Off Publ Arthrosc Assoc N Am Int Arthrosc Assoc. 1997;13:456-60.

2. Hjelle K, Solheim E, Strand T, Muri R, Brittberg M. Articular cartilage defects in 1,000 knee arthroscopies. Arthrosc J Arthrosc Relat Surg Off Publ Arthrosc Assoc N Am Int Arthrosc Assoc. 2002;18:730-4.

3. Bedi A, Feeley BT, Williams RJ. Management of articular cartilage defects of the knee. J Bone Joint Surg Am. 2010;92:994-1009.

4. Chui K, Jeys L, Snow M. Knee salvage procedures: The indications, techniques and outcomes of large osteochondral allografts. World J Orthop. 2015;6:340-50.

5. Gomoll AH, Filardo G, Almqvist FK, Bugbee WD, Jelic M, Monllau JC, et al. Surgical treatment for early osteoarthritis. Part II: allografts and concurrent procedures. Knee Surg Sports Traumatol Arthrosc Off J ESSKA. 2012;20:468-86.

6. Demange $\mathrm{M}, \mathrm{Gomoll} \mathrm{AH}$. The use of osteochondral allografts in the management of cartilage defects. Curr Rev Musculoskelet Med. 2012;5:229-35.

7. Lattermann C, Romine SE. Osteochondral allografts: state of the art. Clin Sports Med. 2009;28:285-301. ix

8. Shasha N, Aubin PP, Cheah HK, Davis AM, Agnidis Z, Gross AE. Long-term clinical experience with fresh osteochondral allografts for articular knee defects in high demand patients. Cell Tissue Bank. 2002;3:175-82.

9. Görtz S, Bugbee WD. Allografts in articular cartilage repair. J Bone Joint Surg Am. 2006:88:1374-84.

10. Gudas R, Kalesinskas RJ, Kimtys V, Stankevicius E, Toliusis V, Bernotavicius G, et al. A prospective randomized clinical study of mosaic osteochondra autologous transplantation versus microfracture for the treatment of osteochondral defects in the knee joint in young athletes. Arthrosc J Arthrosc Relat Surg Off Publ Arthrosc Assoc N Am Int Arthrosc Assoc. 2005;21:1066-75

11. Gudas R, Gudaite A, Pocius A, Gudiene A, Cekanauskas E, Monastyreckiene E, et al. Ten-year follow-up of a prospective, randomized clinical study of mosaic osteochondral autologous transplantation versus microfracture for the treatment of osteochondral defects in the knee joint of athletes. Am J Sports Med. 2012;40:2499-508.

12. Hangody L, Vásárhelyi G, Hangody LR, Sükösd Z, Tibay G, Bartha L, et al. Autologous osteochondral grafting-technique and long-term results. Injury. 2008;39 Suppl 1:S32-9.

13. Tetteh ES, Bajaj S, Ghodadra NS. Basic science and surgical treatment options for articular cartilage injuries of the knee. J Orthop Sports Phys Ther. 2012;42:243-53.
14. LaPrade RF, Botker JC. Donor-site morbidity after osteochondral autograft transfer procedures. Arthrosc J Arthrosc Relat Surg Off Publ Arthrosc Assoc N Am Int Arthrosc Assoc. 2004;20:e69-73.

15. Fritz J, Janssen P, Gaissmaier C, Schewe B, Weise K. Articular cartilage defects in the knee-basics, therapies and results. Injury. 2008;39 Suppl 1:S50-7.

16. Sakata R, Iwakura T, Reddi AH: Regeneration of Articular Cartilage Surface: Morphogens, Cells, and Extracellular Matrix Scaffolds. Tissue Eng Part B Rev 2015, 21:461-473.

17. Ouzzine M, Venkatesan N, Fournel-Gigleux S. Proteoglycans and cartilage repair. Methods Mol Biol Clifton NJ. 2012:836:339-55.

18. Allen RT, Robertson CM, Pennock AT, Bugbee WD, Harwood FL, Wong WW, et al. Analysis of stored osteochondral allografts at the time of surgical implantation. Am J Sports Med. 2005;33:1479-84.

19. Ball ST, Amiel D, Williams SK, Tontz W, Chen AC, Sah RL, et al. The effects of storage on fresh human osteochondral allografts. Clin Orthop 2004, 418:246-252.

20. Gross AE, Kim W, Las Heras F, Backstein D, Safir O, Pritzker KPH. Fresh osteochondral allografts for posttraumatic knee defects: long-term followup. Clin Orthop. 2008;466:1863-70.

21. Görtz S, Bugbee WD. Fresh osteochondral allografts: graft processing and clinical applications. J Knee Surg. 2006;19:231-40.

22. Williams RJ, Ranawat AS, Potter HG, Carter T, Warren RF. Fresh stored allografts for the treatment of osteochondral defects of the knee. J Bone Joint Surg Am. 2007;89:718-26.

23. McCulloch PC, Kang RW, Sobhy MH, Hayden JK, Cole BJ. Prospective evaluation of prolonged fresh osteochondral allograft transplantation of the femoral condyle: minimum 2-year follow-up. Am J Sports Med. 2007;35:411-20.

24. Czitrom AA, Keating S, Gross AE. The viability of articular cartilage in fresh osteochondral allografts after clinical transplantation. J Bone Joint Surg Am. 1990;72:574-81.

25. Pearsall AW, Tucker JA, Hester RB, Heitman RJ. Chondrocyte viability in refrigerated osteochondral allografts used for transplantation within the knee. Am J Sports Med. 2004;32:125-31.

26. Williams SK, Amiel D, Ball ST, Allen RT, Tontz WL, Emmerson BC, et al. Analysis of cartilage tissue on a cellular level in fresh osteochondral allograft retrievals. Am J Sports Med. 2007;35:2022-32.

27. Raz G, Safir OA, Backstein DJ, Lee PTH, Gross AE. Distal Femoral Fresh Osteochondral Allografts: Follow-up at a Mean of Twenty-two Years. J Bone Joint Surg Am. 2014;96:1101-7.

28. Malinin T, Temple HT, Buck BE. Transplantation of osteochondral allografts after cold storage. J Bone Joint Surg Am. 2006;88:762-70.

29. Pallante AL, Bae WC, Chen AC, Görtz S, Bugbee WD, Sah RL. Chondrocyte viability is higher after prolonged storage at 37 degrees $C$ than at 4 degrees C for osteochondral grafts. Am J Sports Med. 2009;37 Suppl 1:24S-32.

30. Abazari A, Jomha NM, Elliott JAW, McGann LE. Cryopreservation of articular cartilage. Cryobiology. 2013;66:201-9.

31. Capeci CM, Turchiano M, Strauss EJ, Youm T. Osteochondral allografts: applications in treating articular cartilage defects in the knee. Bull Hosp Jt Dis. 2013;71:60-7.

32. Williams RJ, Dreese JC, Chen C-T. Chondrocyte survival and material properties of hypothermically stored cartilage: an evaluation of tissue used for osteochondral allograft transplantation. Am J Sports Med. 2004;32:132-9.

33. Ranawat AS, Vidal AF, Chen CT, Zelken JA, Turner AS, Williams RJ. Material properties of fresh cold-stored allografts for osteochondral defects at 1 year. Clin Orthop. 2008;466:1826-36.

34. De Sousa EB, Aguiar DP, Barcelos JFM, Duarte MEL, Olej B. Approaches to preserve human osteochondral allografts. Cell Tissue Bank. 2014.

35. Garrity JT, Stoker AM, Sims HJ, Cook JL. Improved osteochondral allograft preservation using serum-free media at body temperature. Am J Sports Med. 2012:40:2542-8.

36. Cook JL, Stoker AM, Stannard JP, Kuroki K, Cook CR, Pfeiffer FM, et al. A novel system improves preservation of osteochondral allografts. Clin Orthop. 2014;472:3404-14.

37. Pennock AT, Wagner F, Robertson CM, Harwood FL, Bugbee WD, Amiel D. Prolonged storage of osteochondral allografts: does the addition of fetal bovine serum improve chondrocyte viability? J Knee Surg. 2006;19:265-72.

38. Bian L, Stoker AM, Marberry KM, Ateshian GA, Cook JL, Hung CT. Effects of dexamethasone on the functional properties of cartilage explants during long-term culture. Am J Sports Med. 2010;38:78-85.

39. Linn MS, Chase DC, Healey RM, Harwood FL, Bugbee WD, Amiel D. Etanercept enhances preservation of osteochondral allograft viability. Am J Sports Med. 2011;39:1494-9. 
40. Petrera M, De Croos JNA, lu J, Hurtig M, Kandel RA, Theodoropoulos JS. Supplementation with platelet-rich plasma improves the in vitro formation of tissue-engineered cartilage with enhanced mechanical properties. Arthrosc J Arthrosc Relat Surg Off Publ Arthrosc Assoc N Am Int Arthrosc Assoc. 2013;29:1685-92.

41. Xie X, Ulici V, Alexander PG, Jiang Y, Zhang C, Tuan RS. Platelet-Rich Plasma Inhibits Mechanically Induced Injury in Chondrocytes. Arthrosc J Arthrosc Relat Surg Off Publ Arthrosc Assoc N Am Int Arthrosc Assoc. 2015:31:1142-50.

42. Schmidt MB, Chen EH, Lynch SE. A review of the effects of insulin-like growth factor and platelet derived growth factor on in vivo cartilage healing and repair. Osteoarthr Cartil OARS Osteoarthr Res Soc. 2006;14:403-12.

43. Teng MS, Yuen AS, Kim HT. Enhancing osteochondral allograft viability: effects of storage media composition. Clin Orthop. 2008;466:1804-9.

44. Thomas CM, Fuller CJ, Whittles CE, Sharif M. Chondrocyte death by apoptosis is associated with cartilage matrix degradation. Osteoarthr Cartil OARS Osteoarthr Res Soc. 2007;15:27-34.

45. Thomas CM, Fuller CJ, Whittles CE, Sharif M. Chondrocyte death by apoptosis is associated with the initiation and severity of articular cartilage degradation. Int J Rheum Dis. 2011;14:191-8.

46. Kim HT, Teng MS, Dang AC. Chondrocyte apoptosis: implications for osteochondral allograft transplantation. Clin Orthop. 2008;466:1819-25.

47. Robertson CM, Allen RT, Pennock AT, Bugbee WD, Amiel D. Upregulation of apoptotic and matrix-related gene expression during fresh osteochondral allograft storage. Clin Orthop. 2006;442:260-6.

48. Changoor A, Fereydoonzad L, Yaroshinsky A, Buschmann MD. Effects of refrigeration and freezing on the electromechanical and biomechanical properties of articular cartilage. J Biomech Eng. 2010;132:064502.

49. Sim S, Chevrier A, Garon M, Quenneville E, Yaroshinsky A, Hoemann CD, et al. Non-destructive electromechanical assessment (Arthro-BST) of human articular cartilage correlates with histological scores and biomechanical properties. Osteoarthr Cartil OARS Osteoarthr Res Soc. 2014;22:1926-35.

50. Hoemann C, Kandel R, Roberts S, Saris DBF, Creemers L, Mainil-Varlet P, et al. International Cartilage Repair Society (ICRS) Recommended Guidelines for Histological Endpoints for Cartilage Repair Studies in Animal Models and Clinical Trials. Cartilage. 2011;2:153-72.

51. Martin I, Obradovic B, Freed LE, Vunjak-Novakovic G. Method for quantitative analysis of glycosaminoglycan distribution in cultured natural and engineered cartilage. Ann Biomed Eng. 1999;27:656-62.

52. Mankin HJ, Dorfman H, Lippiello L, Zarins A. Biochemical and metabolic abnormalities in articular cartilage from osteo-arthritic human hips. II. Correlation of morphology with biochemical and metabolic data. J Bone Joint Surg Am. 1971;53:523-37.

53. Aigner T, Cook JL, Gerwin N, Glasson SS, Laverty S, Little CB, et al. Histopathology atlas of animal model systems - overview of guiding principles. Osteoarthr Cartil OARS Osteoarthr Res Soc. 2010;18 Suppl 3:S2-6.

54. Bonasia DE, Marmotti A, Massa ADF, Ferro A, Blonna D, Castoldi F, et al. Intra- and inter-observer reliability of ten major histological scoring systems used for the evaluation of in vivo cartilage repair. Knee Surg Sports Traumatol Arthrosc Off J ESSKA 2015, 23:2484-2493.

55. Williams SK, Amiel D, Ball ST, Allen RT, Wong WW, Chen AC, et al. Prolonged storage effects on the articular cartilage of fresh human osteochondral allografts. J Bone Joint Surg Am. 2003;85-A:2111-20.

56. Kiefer GN, Sundby K, McAllister D, Shrive NG, Frank CB, Lam T, et al. The effect of cryopreservation on the biomechanical behavior of bovine articular cartilage. J Orthop Res Off Publ Orthop Res Soc. 1989;7:494-501.

57. Szarko M, Muldrew K, Bertram JE. Freeze-thaw treatment effects on the dynamic mechanical properties of articular cartilage. BMC Musculoskelet Disord. 2010;11:231.

58. Changoor A, Coutu JP, Garon M, Quenneville E, Hurtig MB, Buschmann MD. Streaming potential-based arthroscopic device is sensitive to cartilage changes immediately post-impact in an equine cartilage injury model. J Biomech Eng. 2011;133:061005.

59. D'Lima DD, Hashimoto S, Chen PC, Colwell CW, Lotz MK. Human chondrocyte apoptosis in response to mechanical injury. Osteoarthr Cartil OARS Osteoarthr Res Soc. 2001;9:712-9.

60. Lo MY, Kim HT. Chondrocyte apoptosis induced by collagen degradation: inhibition by caspase inhibitors and IGF-1. J Orthop Res Off Publ Orthop Res Soc. 2004:22:140-4.

61. Abedian R, Willbold E, Becher C, Hurschler C. In vitro electro-mechanical characterization of human knee articular cartilage of different degeneration levels: a comparison with ICRS and Mankin scores. J Biomech. 2013;46:1328-34.
62. Hembree WC, Ward BD, Furman BD, Zura RD, Nichols LA, Guilak F, et al. Viability and apoptosis of human chondrocytes in osteochondral fragments following joint trauma. J Bone Joint Surg Br. 2007:89:1388-95.

63. Kim DY, Taylor HW, Moore RM, Paulsen DB, Cho D-Y. Articular chondrocyte apoptosis in equine osteoarthritis. Vet J Lond Engl 1997. 2003;166:52-7.

64. Matsuo M, Nishida K, Yoshida A, Murakami T, Inoue H. Expression of caspase-3 and -9 relevant to cartilage destruction and chondrocyte apoptosis in human osteoarthritic cartilage. Acta Med Okayama. 2001;55:333-40.

65. Frisbie DD, Cross MW, Mcllwraith CW. A comparative study of articular cartilage thickness in the stifle of animal species used in human pre-clinical studies compared to articular cartilage thickness in the human knee. Vet Comp Orthop Traumatol VCOT. 2006;19:142-6.

\section{Submit your next manuscript to BioMed Central and take full advantage of:}

- Convenient online submission

- Thorough peer review

- No space constraints or color figure charges

- Immediate publication on acceptance

- Inclusion in PubMed, CAS, Scopus and Google Scholar

- Research which is freely available for redistribution 